\title{
Anaemic crisis in sickle cell disease
}

\author{
J. R. MANN, K. P. COTTER, R. A. WALKER, G. W. G. BIRD, AND J. STUART \\ From the Department of Haematology, The Children's Hospital, Birmingham B16 8ET and the Regional \\ Blood Transfusion Service, Vincent Drive, Birmingham B15 $2 S G$
}

SYNOPSIS Sixteen episodes of acute anaemia necessitating urgent blood transfusion have been investigated in 13 children with sickle cell anaemia. In five out of seven episodes there was evidence of increased haemolysis while in 10 out of 16 episodes a profound fall in reticulocyte count indicated marrow erythroid cell failure. Cold agglutinins active at room temperature were detected in 13 episodes, and anti-I specificity was demonstrated in 11. Warmed blood of homologous ABO and Rhesus groups was administered without complication despite difficulty with cross-matching. The exacerbation of anaemia was not due to folate lack, glucose-6-phosphate dehydrogenase deficiency or splenic sequestration, and an infectious agent appeared responsible.

The degree of anaemia in homozygous sickle cell disease is usually constant during asymptomatic periods. An episode of sudden profound anaemia (anaemic crisis) may, however, result from marrow hypoplasia, an exacerbation of haemolysis, splenic sequestration, or folate deficiency.

Sixteen episodes of sudden anaemia requiring blood transfusion have been observed in 13 children attending this hospital between June 1971 and April 1973. These episodes, which were lifethreatening in some patients, occurred despite daily folate supplements. The haematological, microbiological, and clinical data are presented to illustrate possible mechanisms and difficulties in management.

\section{Patients and Methods}

The patients studied were aged from 3 to 18 years. Eight had homozygous sickle cell disease while the remaining five may have suffered from sickle cell thalassaemia since family studies were incomplete. The patients routinely attended a haemoglobinopathy clinic and received daily folic acid (5 mg) supplements. Glucose-6-phosphate dehydrogenase deficiency was excluded.

Episodes 1 to 9 were studied retrospectively while episodes 10 to 16 were investigated in more detail prospectively. Haematological and serological tests were performed using standard methods (Dacie and Lewis, 1968), methaemalbumin was estimated by the method of Schumm (Varley, 1967), and haemoglobinuria was detected by spectroscopic examination. The following tests were performed on admission in the prospective study: chest radioReceived for publication 11 December 1974. graph; haemoglobin level; haematocrit; reticulocyte count; white cell count and differential; platelet count; blood culture; serological tests for erythrocyte auto-antibody formation; throat swab for bacterial culture and virus isolation; stool for virus isolation; Paul-Bunnell; and complement fixation tests for antibodies to herpes simplex, mumps soluble, mumps viral, influenza $A, B$, and C, parainfluenza 1, $Q$ fever, psittacosis group, respiratory syncytial virus, adenovirus, cytomegalovirus, measles, rubella, and Mycoplasma pneumoniae. The haematological tests and complement fixation studies were repeated during the convalescent phase of the illness.

When cold agglutinins caused difficulty with cross-matching warmed blood of homologous $\mathrm{ABO}$ and Rhesus groups was given. Packed red cells were transfused via a blood-warming coil immersed in a water bath at $37^{\circ} \mathrm{C}$.

\section{Results}

The haematological results are shown in the table. The mean fall in haemoglobin level, calculated from the average haemoglobin level for each individual patient during the previous year, was $3.9 \mathrm{~g} / \mathrm{dl}$ (range 1-3-5.7) and all patients required transfusion.

Ten of the 16 episodes were associated with a very low reticulocyte count on admission compared with the average figure for the previous year; 


\begin{tabular}{|c|c|c|c|c|c|c|c|c|c|}
\hline Episode & $\begin{array}{l}\text { Age } \\
(y r)\end{array}$ & $\begin{array}{l}H b \\
(g / d l)\end{array}$ & $\begin{array}{l}\text { Retics } \\
(\%)\end{array}$ & $\begin{array}{l}\text { Normoblasts } \\
\text { (per } 100 \\
W B C)\end{array}$ & $\begin{array}{l}\text { Total } \\
\text { Bilirubin } \\
(\mathrm{mg} / 100 \mathrm{ml})\end{array}$ & $\begin{array}{l}\text { Methaem- } \\
\text { albumin- } \\
\text { aemia }\end{array}$ & $\begin{array}{l}\text { Cold Agglutinins } \\
\text { (specificity and } \\
\text { titre) }\end{array}$ & $\begin{array}{l}\text { Spleen } \\
(\mathrm{cm})\end{array}$ & $\begin{array}{l}\text { Presenting } \\
\text { Illness }\end{array}$ \\
\hline 1 & 7 & $\begin{array}{c}3 \cdot 8 \\
(8 \cdot 0)^{1}\end{array}$ & $\begin{array}{c}3 \cdot 8 \\
(18 \cdot 3)\end{array}$ & 0 & - & - & $\begin{array}{l}\text { Anti-I } \\
\text { Anti-HI }\end{array}$ & $1 \cdot 5$ & $\begin{array}{l}\text { Pneumonia and } \\
\text { painful crisis }\end{array}$ \\
\hline 2 & 18 & $\begin{array}{c}4 \cdot 2 \\
(9 \cdot 9)\end{array}$ & $\begin{array}{c}0 \\
(21 \cdot 0)\end{array}$ & 0 & - & - & Anti-c & 0 & Pneumonia \\
\hline 3 & 9 & $\begin{array}{c}4 \cdot 6 \\
(8 \cdot 8)\end{array}$ & $\begin{array}{c}0.5 \\
(16.5)\end{array}$ & 0 & - & - & Absent & 8 & $\begin{array}{l}\text { URTI and } \\
\text { painful crisis }\end{array}$ \\
\hline 4 & 4 & $\begin{array}{c}4 \cdot 0 \\
(8 \cdot 7)\end{array}$ & $\begin{array}{c}5 \cdot 3 \\
(12 \cdot 0)\end{array}$ & $\mathbf{0}$ & - & - & Absent & $\mathbf{0}$ & URTI \\
\hline 5 & 3 & $\begin{array}{c}5 \cdot 8 \\
(9 \cdot 2)\end{array}$ & $\begin{array}{c}3 \cdot 0 \\
(11 \cdot 5)\end{array}$ & 8 & - & - & $\begin{array}{l}\text { Present, type not } \\
\text { determined }\end{array}$ & 3 & Pneumonia \\
\hline 6 & 11 & $\begin{array}{c}5 \cdot 4 \\
(8 \cdot 5)\end{array}$ & $(13 \cdot 7)$ & 120 & - & - & $\begin{array}{l}\text { Anti-I } \\
\text { Anti Lewis }\end{array}$ & Tip & Painful crisis \\
\hline 7 & 5 & $\begin{array}{c}2 \cdot 8 \\
(8 \cdot 4)\end{array}$ & $\begin{array}{c}0 \cdot 5 \\
(20 \cdot 7)\end{array}$ & 0 & - & - & Anti-I & 4 & Painful crisis \\
\hline 8 & 7 & $\begin{array}{c}2 \cdot 7 \\
(7 \cdot 5)\end{array}$ & $\begin{array}{c}0 \cdot 5 \\
(15 \cdot 3)\end{array}$ & 0 & - & - & Anti-I & Tip & Painful crisis \\
\hline 9 & 4 & $\begin{array}{c}3 \cdot 2 \\
(8 \cdot 6)\end{array}$ & $\begin{array}{c}2 \\
(25 \cdot 4)\end{array}$ & 200 & - & - & Anti-I & Tip & Pneumonia \\
\hline 10 & 8 & $\begin{array}{c}4 \cdot 7 \\
(7 \cdot 7)\end{array}$ & $\begin{array}{c}5 \cdot 6 \\
(18 \cdot 0)\end{array}$ & 0 & $\begin{array}{l}6 \cdot 5 \\
(2 \cdot 1)^{1}\end{array}$ & Present & $\begin{array}{l}\text { Anti-I } \\
1: 128\end{array}$ & 0 & Pneumonia \\
\hline 11 & 4 & $\begin{array}{c}5 \cdot 6 \\
(8 \cdot 6)\end{array}$ & $\begin{array}{c}13.4 \\
(19.9)\end{array}$ & 24 & $\begin{array}{c}2 \cdot 2 \\
(-)\end{array}$ & Absent & $\begin{array}{l}\text { Anti-I } \\
1: 256\end{array}$ & 0 & Pneumonia \\
\hline 12 & 9 & $\begin{array}{c}5 \cdot 6 \\
(7 \cdot 9)\end{array}$ & $\begin{array}{c}17 \cdot 6 \\
(19 \cdot 6)\end{array}$ & 155 & $\begin{array}{l}3 \cdot 6 \\
(2 \cdot 7)\end{array}$ & Present & $\begin{array}{l}\text { Anti-I } \\
1: 4\end{array}$ & 0 & $\begin{array}{l}\text { Septicaemia, } \\
\text { osteomyelitis, and } \\
\text { haemoglobinuria }\end{array}$ \\
\hline 13 & 9 & $\begin{array}{l}46 \\
(6 \cdot 6)\end{array}$ & $\begin{array}{c}29 \cdot 0 \\
(21 \cdot 0)\end{array}$ & 0 & $\begin{array}{c}5 \cdot 6 \\
(3 \cdot 6)\end{array}$ & Present & $\begin{array}{l}\text { Anti-I } \\
1: 16\end{array}$ & 0 & Pneumonia \\
\hline 14 & 7 & $\begin{array}{c}4 \cdot 8 \\
(8 \cdot 8)\end{array}$ & $\begin{array}{c}7 \cdot 0 \\
(10 \cdot 3)\end{array}$ & 100 & $\begin{array}{c}0.6 \\
(-)\end{array}$ & Absent & $\begin{array}{l}\text { Anti-I } \\
1: 4\end{array}$ & 0 & Painful crisis \\
\hline 15 & 9 & $\begin{array}{c}5 \cdot 3 \\
(6 \cdot 6)\end{array}$ & $\begin{array}{c}28 \cdot 4 \\
(21 \cdot 0)\end{array}$ & 3 & $\begin{array}{c}8.9 \\
(1 \cdot 5)\end{array}$ & Present & Absent & 0 & $\begin{array}{l}\text { Pneumonia and } \\
\text { haemoglobinuria }\end{array}$ \\
\hline 16 & 16 & $\begin{array}{c}3 \cdot 2 \\
(8 \cdot 3)\end{array}$ & $\begin{array}{l}<0 \cdot 1 \\
(15 \cdot 2)\end{array}$ & 30 & $\begin{array}{l}5 \cdot 6 \\
(2 \cdot 2)\end{array}$ & - & Anti-I & 0 & Painful crisis \\
\hline
\end{tabular}

Table Haematological values in 16 episodes of acute exacerbation of anaemia in 13 patients

'Haemoglobin values in parentheses represent the mean value for outpatient attendances during the previous year, and bilirubin values in parentheses the mean levels in the convalescent period.

URTI = Upper respiratory track infection.

this implies that there had been marrow erythroid cell insufficiency. However in three of these 10 reticulocytopenic children erythroblasts were present in the peripheral blood, consistent with early erythroid cell regeneration (MacIver and ParkerWilliams, 1961). Serum bilirubin and methaemalbumin levels were not determined in the patients studied retrospectively. However, five of the seven patients studied prospectively showed methaemalbumin and/or unconjugated hyperbilirubinaemia. Haemoglobinuria occurred in patients 12 and 15 . In episodes 10 and 16 hyperhaemolysis co-existed with reticulocytopenia. The haematological findings in the acute stage which suggested hyperhaemolysis and/or decreased erythrocyte production returned to pre-admission steady-state values during convalescence.

Cold agglutinins were detected in 13 of the 16 episodes and were active at both $4^{\circ} \mathrm{C}$ and room temperature in all 13 , and at $37^{\circ} \mathrm{C}$ in three. Where estimated, the antibody titre was 1:256 or lower.
Anti-I specificity was demonstrated in 11 episodes There was no evidence of a strong $\mathrm{i}$ antigen as reported in congenital anaemias.

Thus, of the nine patients studied retrospectively, 0 evidence of erythroid insufficiency was present in eight, and six of the eight had cold agglutinins. In the seven episodes studied prospectively, two patients had evidence of both erythroid insufficiency o and hyperhaemolysis, three showed hyperhaemolysis $N$ alone, and six had cold agglutinins with anti-I N specificity.

In patient 12, pneumonia, septicaemia, and

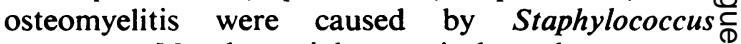
pyogenes. No bacterial or viral pathogen was $\stackrel{?}{?}$ isolated from any of the other patients. However, $D$ patients 10 and 11 showed evidence of Mycoplasma 0 뭉 pneumoniae infection, their mycoplasmal comple- $\stackrel{\mathbb{Q}}{\Omega}$ ment fixation titres rising from $<1: 8$ on admission $\mathbb{\Phi}$ to $1: 512$ and $1: 256$ respectively during convalescence, while clinical features of atypical pneumonia and cold agglutinins with anti-I specificity 
(titres $1: 128$ and 1:256) were also present. None of the other patients had significant elevation of viral complement fixation titres despite radiological and clinical changes consistent with pulmonary infection in eight of them.

Episodes 6, 7, 8, and 9 occurred almost simultaneously among the children of one family. Episodes 2, 3, and 4, and episodes 10 and 11 also occurred simultaneously in siblings. This lends support to an infective aetiology despite inability to identify the causative agent in most of the children.

There was no clinical evidence of an increase in spleen size in any of the patients; it was impalpable on nine occasions and just palpable on four. All patients showed either a normal leucocyte count and differential or a leucocytosis (range 4.8-60.0 $\left.\times 10^{9} / 1\right)$. Platelet counts were normal or raised (range 247-966 $\times 10^{9} / 1$ ) except in the septicaemic patient who was thrombocytopenic with an impalpable spleen for several days. Thus splenic sequestration was not responsible for the sudden fall in haemoglobin level.

\section{Discussion}

The term 'crisis' as applied to sickle cell disease is commonly used to describe the painful, vasoocclusive episodes of tissue infarction. It may also be used to describe episodes of severe anaemia, and this latter form of crisis has been sub-classified into aplastic, hyperhaemolytic, and combined aplastic-hyperhaemolytic types (Singer, Motulksy, and Wile, 1950). Sudden anaemia may also result from splenic enlargement and sequestration of erythrocytes (Jenkins, Scott, and Baird, 1960). Folate-responsive anaemia may result from chronic haemolysis alone (Lindenbaum and Klipstein, 1963) but is more common in patients with an additional precipitating factor such as infancy (MacIver and Went, 1960) or pregnancy (Jonsson, Roath, and Kirkpatrick, 1959).

Diggs (1956) reported only one aplastic crisis in a series of 747 admissions for crisis but MacIver and Parker-Williams (1961) reported 12 episodes, 10 of which were seen in a seven-month period, and Charney and Miller (1964) reported nine episodes in 20 children followed over a five-year period. These authors reported that aplastic crises were more common than previously described but they considered that hyperhaemolytic crises rarely, if ever, occurred. This view was also held by Singer et al (1950), Chernoff (1955), Diggs (1956), Zuelzer (1959), and Hilkovitz (1960). Wright and Gardner (1960), in contrast, referred to 23 admissions for acute haemolytic crisis but gave no supporting clinical or laboratory details.

It is difficult to determine the relative importance of hyperhaemolysis as compared with marrow erythroid cell failure in our patients, since the timing of investigation in relation to the stage of the illness is critical. Clear evidence of reticulocytopenia was found in 10 episodes, and in five of these the reticulocyte count was less than $1 \%$. In the seven prospective studies, the serum bilirubin increased slightly or markedly in five, the reticulocytosis was maintained or increased in four, methaemalbuminaemia occurred transiently in four, and haemoglobinuria in two. Thus patients receiving folate supplements may show episodes of increased haemolysis with or without failure of erythroid cell production. The selective failure of the erythroid cell line with maintenance of normal or raised leucocyte and platelet counts is consistent with earlier descriptions of 'aplastic' episodes (Charney and Miller, 1964).

The presence of cold agglutinins in 13 patients was associated with painful crises in five, with evidence of pulmonary infection in seven, and with both in one patient. Cold agglutination has previously been described in $60 \%$ of 30 patients with sickle cell anaemia, but there was no correlation with haemoglobin level or clinical status (McSweeney, Mermann, and Wagley, 1947) and the antibody was not specified. Cold agglutination has also been observed in a sickle cell heterozygote with limb gangrene and respiratory infection (McGucken, 1972), in a patient with sickle cell/HbC disease who developed arterial occlusion associated with pneumonia (Burchmore, Buckle, Lehmann, and Jenkins, 1962) and in six children with vasoocclusive sickle cell crisis (Charmot, Reynaud, and Bergot, 1963). Although the cold agglutinin titres in our own patients were low, the tests were performed with cells in saline only; it has recently been observed (Haynes and Chaplin, 1971; Bird and Wingham, 1973) that the titres of some anti-I agglutinins are greatly enhanced by the addition of albumin and that such antibodies may be responsible for haemolytic episodes.

The presence of cold agglutinins of anti-I specificity in 11 episodes together with non-bacterial pneumonia in five of the 11 suggests the possibility of Mycoplasma pneumoniae infection, and our patients' illnesses coincided with the 1971-2 Mycoplasma pneumoniae epidemic (Noah, 1974). However, it is not possible to differentiate accurately between pneumonia and pulmonary infarction in children with sickle cell anaemia. Moreover, only two patients had elevated mycoplasmal complement fixation titres and, even though these antibodies tend to be short-lived (Hers, 1968), the timing of the 
first blood specimen was related to the subsequent onset of severe anaemia when complement fixing antibodies might still have been detectable.

Other workers (Leikin, 1957; MacIver and Parker-Williams, 1961) have suspected, but failed to confirm, a viral aetiology for aplastic crises in sickle cell anaemia, and have also described simultaneous anaemia in siblings, but have not specifically considered Mycoplasma pneumoniae as a possible cause. Shulman, Bartlett, Clyde, and Ayoub (1972) reported unusually severe mycoplasmal pneumonia in five children with sickle cell disease but did not draw attention to an association with severe anaemia, though two of their patients did require blood transfusion. Our results will have been influenced by the mycoplasma epidemic but it seems possible that children with sickle cell anaemia are unduly susceptible to mycoplasmal, as well as to other infections (Barrett-Connor, 1971; Seeler, Metzger, and Mufson, 1972; Bromberg, 1974).

Children with sickle cell disease are therefore prone to episodes of erythroid hypoplasia and hyperhaemolysis despite daily folate supplements. When a fall in haemoglobin level occurs, blood should be taken into a syringe and container at $37^{\circ} \mathrm{C}$ in order to reduce subsequent blood group and cross-match difficulties in the presence of cold agglutinins active at room temperature. The haemoglobin level and reticulocyte count should also be checked simultaneously in any sibling with congenital haemolytic anaemia. Urgent transfusion may be life-saving, and warmed, apparently incompatible, blood of homologous $\mathrm{ABO}$ and Rhesus groups may require to be transfused without delay.

Financial support was provided by the Birmingham Central Health District Trust Funds. We should like to thank Dr T. H. Flewett of the Regional Virology Laboratory, East Birmingham Hospital and $\mathrm{Mr} \mathrm{D}$. R. Purdham for performing the viral studies.

\section{References}

Barrett-Connor, E. (1971). Acute pulmonary disease and sickle cell anemia. Amer. Rev. resp. Dis., 104, 159-165.

Bird, G. W. G. and Wingham, J. (1973). Anti-I autoantibody acting preferentially in albumin. (Abstr.) Brit. J. Haemat., 25, 280-281.

Bromberg, P. A. (1974). Pulmonary aspects of sickle cell disease. Arch. intern. Med., 133, 652-657.

Burchmore, J. W., Buckle, R. M., Lehmann, H., and Jenkins, W. J. (1962). Agglutinating-sickling arterial thrombosis. Lancet, 2, 1008-1010.
Charmot, G., Reynaud, R., and Bergot, J. (1963). Cryoglobulinaemia and cold agglutinins in painful crises of sickle-cell anaemia. Lancet, 2, 540.

Charney, E. and Miller, G. (1964). Reticulocytopenia in sickle cell disease. Amer. J. Dis. Child., 107, 450-455.

Jenkins, W. J. (1962). Agglutinating-sickling arterial thrombosis. Lancet, 2, 1008-1010.

Chernoff, A. I. (1955). The human hemoglobins in health and disease. (Part 2). New Engl. J. Med., 253, 365-374.

Dacie, J. V. and Lewis, S. M. (1968). Practical Haematology, कै 4th ed. Churchill, London.

Diggs, L. W. (1956). The crisis in sickle cell anemia. Amer. J. clin. Path., 26, 1109-1118.

Haynes, C. R. and Chaplin, H., Jr. (1971). An enhancing effect of albuimin on the determination of cold hemagglutinins. Vox Sang. (Basel), 20, 46-54.

Hers, J. F. P. (1968). Clinical aspects of infection with Mycoplasma pneumoniae. Proc. roy. soc. Med., 61, $\infty$ 1325-1330.

Hilkovitz, G. (1960). Sickle-cell disease. Arch. intern. Med., 105, 76-82.

Jenkins, M. E., Scott, R. B., and Baird, R. L. (1960). Studies O in sickle cell anemia. XVI. Sudden death during sickle cell anemia crises in young children. J. Pediat., 56, 30-38.

Jonsson, U., Roath, O. S., and Kirkpatrick, C. I. F. (1959). Nutritional megaloblastic anemia associated with sickle cell states. Blood, 14, 535-547.

Leikin, S. L. (1957). The aplastic crisis of sickle-cell disease. जै Amer. J. Dis. Child., 93, 128-139.

Lindenbaum, J. and Klipstein, F. A. (1963). Folic acid deficiency in sickle-cell anemia. New Engl. J. Med., 269, 875-882.

McGucken, R. B. (1972). Bilateral gangrene of the feet in a Nigerian infant. (Letter). Lancet, 1, 852.

MacIver, J. E. and Parker-Williams, E. J. (1961). The $\mathbb{D}$ aplastic crisis in sickle-cell anaemia. Lancet, 1, 1086-1089.

MacIver, J. E. and Went, L. N. (1960). Sickle-cell anaemia 음 complicated by megaloblastic anaemia of infancy. Brit. $\exists$ med. J., 1, 775-779.

McSweeney, J. E. J., Mermann, A. C., and Wagley, P. F. (1947). Cold hemagglutinins in sickle cell anemia. Amer. J. med. Sci., 214, 542-544.

Noah, N. D. (1974). Mycoplasma pneumoniae infection in the United Kingdom-1967-73. Brit. med., J., 2, 544-546.

Seeler, R. A., Metzger, W., and Mufson, M. A. (1972). Diplococcus pneumoniae infections in children with sickle cell anemia. Amer. J. Dis. Child., 123, 8-10.

Shulman, S. T., Bartlett, J., Clyde, W. A., Jr., and Ayoub, E. M. (1972). The unusual severity of mycoplasmal pneumonia in children with sickle-cell disease. New Engl. J. Med., 287, 164-167.

Singer, K., Motulsky, A. G., and Wile, S. A. (1950). Aplastic crisis in sickle cell anemia: a study of its mechanism and $\sigma$ its relationship to other types of hemolytic crises. J. Lab. clin. Med., 35, 721-736.

Varley, H. (1967). Practical Clinical Biochemistry, 4th ed., N p. 584. Heinemann, London.

Wright, C. S. and Gardner, E., Jr. (1960). A study of the role of acute infections in precipitating crises in chronic hemolytic states. Ann. intern. Med., 52, 530-537.

Zuelzer, W. W. (1959). Clinical and haematological aspects of various haemoglobin syndromes. In Abnormal Haemo- $\square$ globins, edited by J. H. P. Jonxis and J. F. Delafresnaye, p. 100-113. Blackwell, Oxford. 